\title{
CAMBRIDGE
}

WINNER of the Social Issues in Management division's Best Book award, presented at the Academy of Management 2014:

\section{CORPORATE RESPONSIBILITY}

THE AMERICAN EXPERIENCE Archie B. Carroll, University of Georgia Kenneth J. Lipartito, Florida International University James E. Post, Boston University Patricia H. Werhane, DePaul University, Chicago Kenneth E. Goodpaster, University of St Thomas, Minnesota

A landmark history of corporate responsibility, showing the changes in corporate power and business behaviour since the mid-eighteenth century.

If A must read for anyone concerned about the future of capitalism in our society.

Bill George, Harvard Business School

\section{CORPORATE RESPONSIBILITY \\ THE AMERICAN EXPERIENCE}

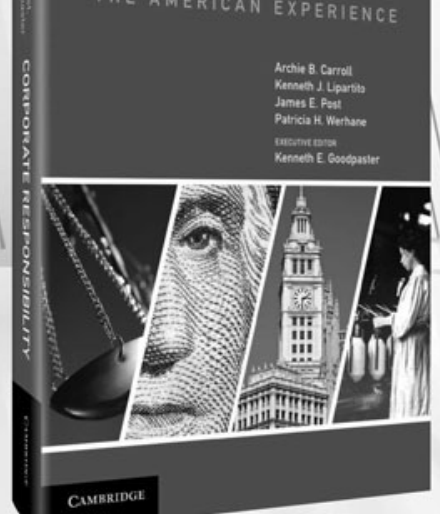

Paperback | 978-1-107-60525-1 | \$51.00 / £31.99

Hardback | 978-1-107-02094-8 | \$130.00 / £78.00

Read more at

www.cambridge.org/9781107605251

CAMBRIDGE UNIVERSITY PRESS 
guarterly, spring, semer, Nutum and winter-

Contere

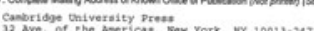

9231.00

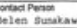

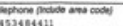

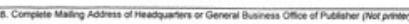

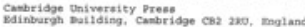

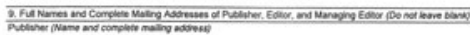

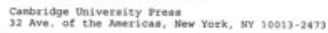

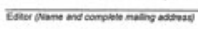

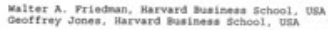

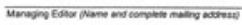

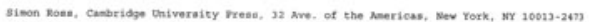

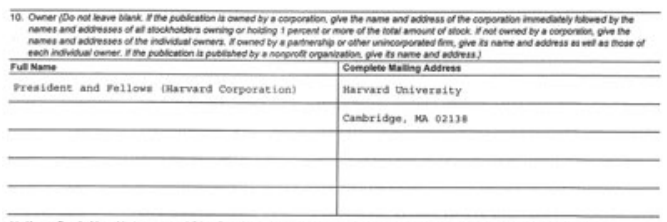

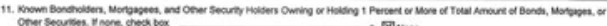
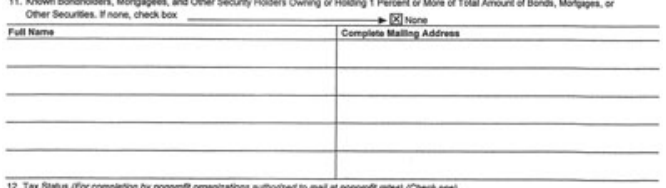

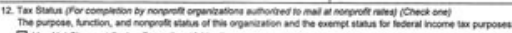

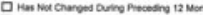

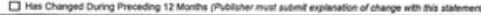

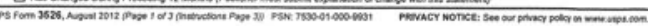

12. Pelcobocon Thio

Business History Revier

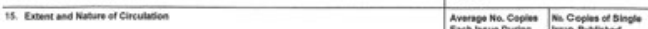

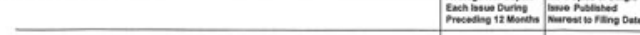

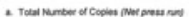

\begin{tabular}{l|l|l|c|c}
\hline & 960 & 395 \\
\hline
\end{tabular}

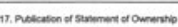

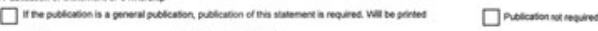

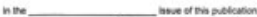

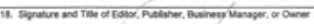

$$
\text { Heller vecaldien }
$$

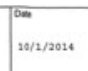

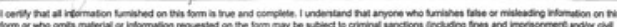

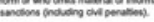

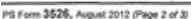




\section{GUIDELINES FOR CONTRIBUTORS}

Business History Review seeks articles drawn from rigorous primary research that address major debates and offer comparative perspectives. We consider the history of entrepreneurs, firms, and business systems, and the subjects of innovation, globalization, and regulation. We are also interested in the relation of businesses to political regimes and the environment.

Manuscripts are considered for publication on the understanding that they are not currently under consideration elsewhere and that the material-in substance as well as form-has not been previously published.

Manuscripts should be submitted by e-mail to bhr@hbs.edu.

Authors of accepted manuscripts will receive a copy of the issue in which their article appears and a pdf file.

We encourage $B H R$ authors to make their abstracts available on SSRN after the publication of their articles.

\section{MANUSCRIPT PREPARATION}

Authors must remember not to identify themselves in the body of the manuscript; specifically, references to their own work in the text should be in the third person, and citations should be written without possessive pronouns-not "See my ..."

We use the 16th edition of The Chicago Manual of Style (2010) and spell and hyphenate words according to Merriam-Webster's Collegiate Dictionary.

Send a bio of three to four sentences, stating affiliation and recent publications.

Be sure to include an abstract of no more than 100 words outlining the main point(s) of the paper and placing the article in context. Subheads should be used to divide the manuscript into three or four sections (or more, depending on length).

Articles should not be more than 10,000 words in length, including footnotes.

Each table and figure must be accompanied by a complete source.

When submitting figures, make sure to include the data files. Tables should be prepared in a Word format to facilitate in-house editing.

Authors are responsible for obtaining all illustrative materials and permissions for reproduction, and for writing captions.

The journal encourages authors to use gender-neutral prose in all cases where it is not anachronistic to do so; male nouns and pronouns should not be used to refer to people of both sexes.

We use the day-month-year form for dates in citations, as 11 February 2007.

Double quotation marks should be used for journal article titles and direct quotation; single quotation marks are used for quoted material inside quotations.

\section{SAMPLE CITATIONS}

BOOK: Thomas K. McCraw, Prophet of Innovation: Joseph Schumpeter and Creative Destruction (Cambridge, Mass., 2007), 205-21.

JOURNAL: Naomi R. Lamoreaux, "Scylla or Charybdis? Historical Reflections on Two Basic Problems of Corporate Governance," Business History Review 83 (Spring 2009): 9-34.

Note that we do not include the publisher in book citations. We do not use loc. cit., op. cit., or idem., but ibid. (not italicized) may be used.

\section{EDITORIAL OFFICE}

Business History Review

Harvard Business School

Soldiers Field

Boston, MA 02163, USA

Tel.: $+1617-495-1003$

Fax: +1 617-495-2705

E-mail: bhr@hbs.edu

www.hbs.edu/businesshistory/publications

\section{BUSINESS OFFICE}

Cambridge University Press

The Edinburgh Building

Shaftesbury Road

Cambridge CB2 8RU, UK

Tel.: +44 1223326498

Fax: +44 1223325801

E-mail: journals@cambridge.org

www.journals.cambridge.org/bhr 


\section{BUSINESS HISTORY REVIEW}

Mary O'Sullivan, A Fine Failure: Relationship Lending, Moses Taylor, and the Joliet Iron \& Steel Company, 1869-1888

Adoración Álvaro-Moya, The Globalization of Knowledge-Based Services: Engineering Consulting in Spain, 1953-1975

Álvaro Silva, Organizational Innovation in Nineteenth-Century Railway Investment: Peripheral Countries in a Global Economy

Andrew Cohen, Britain and the Breakdown of the Colonial Environment: The Struggle over the Tanzam Oil Pipeline in Zambia

Cory Davis, The Political Economy of Commercial Associations: Building the National Board of Trade, 1840-1868

ReVIEw EssaY

Mira Wilkins and Frank Ernest Hill, American Business Abroad: Ford on Six Continents. New edition with a new introduction by Mira Wilkins. Reviewed by Patrick Fridenson

Harvard Business SCHOol

BOSTON MA 02163

BHR@HBS.EDU 